\title{
ANALYSIS AND DESIGN OF STRUCTURAL STEEL JOINTS AND CONNECTION: SOFTWARE IMPLEMENTATION
}

\author{
Viktor S. Karpilovsky ${ }^{1}$, Eduard Z. Kriksunov ${ }^{\text {, Anatoly V. Perelmuter }}{ }^{1}$, \\ Vitalina $V$. Yurchenko ${ }^{2}$ \\ ${ }^{1}$ SCAD Soft Ltd., Kyiv, UKRAINE \\ ${ }^{2}$ Kyiv National University of Civil Engineering and Architecture, Kyiv, UKRAINE
}

\begin{abstract}
The paper presents COMET software which enables to design steel structural joints widely used in civil and industrial engineering. Algorithm for designing each joint prototype has been presented as a set of operations implementing the rules for determining the interrelated values of the joint parameters. Each prototype is developed as an independent program that performs a full cycle of designing the joint and verification of the joint parameters according to the specified design codes.

Searching of unknown joint parameters has been transformed to a decision making problem based on analysis of the joint mathematical model. Automatic searching of unknown joint parameters has been implemented as a multiple targeted improvement of a certain initial joint design in order to satisfy load-carrying capacity constraints taking into account the structural and assortment-based constraints. Multiple improvement of current joint design is performed on the basis of sensitivity analysis relative to variation of governing joint parameters.
\end{abstract}

Keywords: structural steel joint, decision making problem, sensitivity analysis, software implementation.

\section{О ПРОГРАММНОЙ РЕАЛИЗАЦИИ РАСЧЕТА И ПРОЕКТИРОВАНИЯ УЗЛОВ И СОЕДИНЕНИЙ СТАЛЬНЫХ КОНСТРУКЦИЙ}

\author{
В.С. Карпиловский ${ }^{1}$, Э.З. Криксунов ${ }^{1}$, А.В. Перельмутер ${ }^{1}$, В.В. Юрченко ${ }^{2}$ \\ ${ }^{1}$ SCAD Soft Ltd., Киев, УКРАИНА \\ ${ }^{2}$ Киевский национальный университет строительства и архитектуры, Киев, УКРАИНА
}

\begin{abstract}
Аннотация. В статье представлена программа КОМЕТА, позволяющая рассчитывать и проектировать узлы металлических конструкций, широко используемые в промышленном и гражданском строительстве. Алгоритм проектирования каждого прототипа узла представлен в виде набора операций, реализующих правила определения значений взаимосвязанных параметров узлов. Для каждого прототипа узла разработан независимый модуль программы, выполняющий полный цикл проектирования узла и проверки его параметров на соответствие выбранным нормам проектирования.

Задача поиска неизвестных параметров узлов стальных конструкций представлена как проблема принятия решений на основе анализа математической модели узла. Автоматический поиск неизвестных значений параметров узла реализован как многократное целенаправленное улучшение некоторого исходного проектного решения с целью удовлетворения ограничений несущей способности, а также с учетом конструктивных и сортаментных ограничений. Многократное улучшение текущего проектного решения узла выполняется на основе анализа чувствительности по отношению к варьированию управляющих параметров узла.
\end{abstract}

Ключевые слова: узел стальной конструкции, проблема принятия решений, анализ чувствительности, программная реализация. 


\section{INTRODUCTION}

Design and analysis of joints is one of the most important stages of design of steel structures. Unlike the stress-strain state analysis on the basis of the design model, which follows the strict rules of structural mechanics, "algorithms" for the analysis of joints use the traditional methods (taking into account the previous experience) of approximate solutions, which are based on a simplified representation of the behavior of joints. These methods are usually closely related to the set of proven designs of joints (prototypes) used for this type of structures.

Despite the variety of prototypes of joints of one type (for example, columns bases), the number of parameters that have to be determined for each of them in the design process is limited. Taking into account the peculiarities of the behavior of a certain prototype of the joint in the structure (e.g., the cross sections of structural elements coming into the joint, loads taken by the joint etc.), and the requirements of various design codes, the algorithm for designing each joint prototype should be presented as a set of operations implementing the rules for determining the interrelated values of the parameters. Each prototype is developed as an independent procedure that performs a full cycle of designing the joint, check of the parameters according to the specified design codes, as well as the generation of a drawing of the designed joint. Taking into account the fact that regardless of the selected prototype most of the parameters of the same purpose of the joints of the same type are determined according to the same rules, the software implementation of parametric prototypes comes down to the organization of information exchange between different software modules that serve to determine the specific parameters. The focus on the use of parametric prototypes of joints that meet the above requirements has been adopted in the first programs developed by SCAD Soft Ltd. since the mid-1990s and implemented in software COMET [3]. A similar approach to the solution of the problem of designing steel structural joints has been also used by other developers of CAD-CAE systems, for example, RFEM and RSTAB modules of Dlubal Software [1], Connections modules of
Autodesk Robot Structural Analysis Professional [5] or STK-SAPR and ESPRI of LIRA-SAPR.

\section{PARAMETRIC PROTOTYPES ORIENTATION}

The current version of COMET, which will be further considered, enables to design steel structural joints widely used in civil and industrial engineering [3], [4]. The application is also used to perform a structural appraisal of a steel joint according to the requirements of Ukrainian codes (DBN B 2.6-163: 2010 or DBN B 2.6-198: 2014), Russian codes (SNiP II-23-81*, SP 53-103-2004 or SP 16.13330.2011) and European codes (EN 1993-18, EN 1993-1-1). Among other things, the selection of codes defines the set of prototypes of joints proposed for the analysis, which includes only the joints that are reflected in the text of the codes.

The COMET software provides the following groups of prototypes for steel structural joints: nominally pinned and rigid column bases, beam and rafter splices, hinged and rigid joints between columns and rafters, and truss joints.

The set of parametric prototypes for each type of joint has been determined on the basis of different requirements, the consideration of which has affected not only the selected designs,

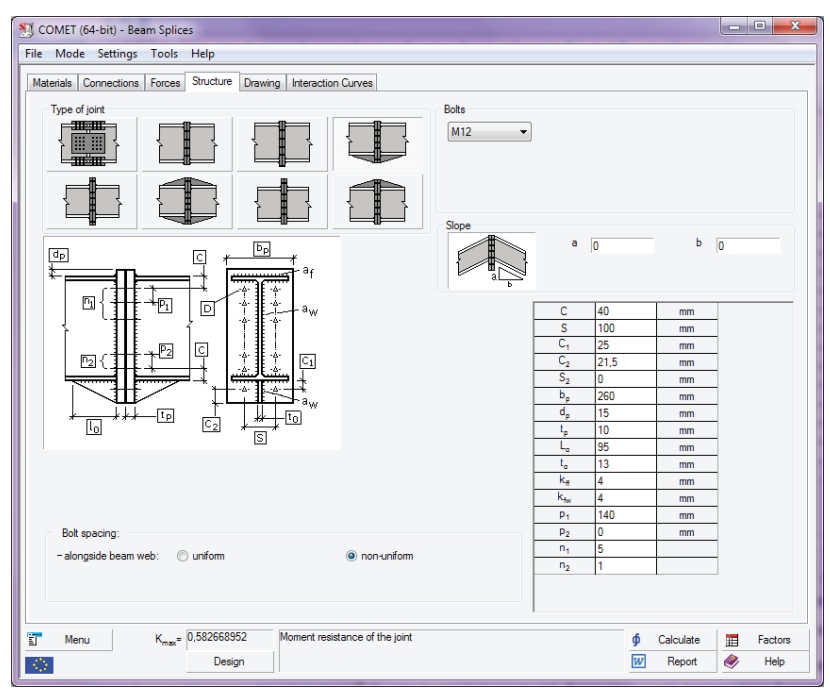

Figure 1. Set of prototypes of the design of beam splices. 
but also the parameters necessary for their implementation.

A set of prototypes implemented for beam splices is given as an example in Fig. 1.

The joint prototype is selected by the designer. Only formal checks are performed at the stage of the data input (e.g. correspondence of the set of force factors to the selected joint prototype). Once the calculation is completed, it is up to the designer whether to accept or reject the analyzed design. Given that the time of the calculation of joint is comparable with the time it takes to press a "button" invoking this operation, it becomes possible to analyze other options and make a justified decision.

\section{SOFTWARE IMPLEMENTATION}

\section{Conceptual provisions and flowchart}

The conceptual basis of the project was the idea of creating a program with the following functions: - automatic determination of all parameters of the joint which formally satisfies the requirements of design codes for the given internal forces combinations;

- automatic determination of some parameters of the joint, taking into account the fact that other parameters are specified by the user and can not be changed;

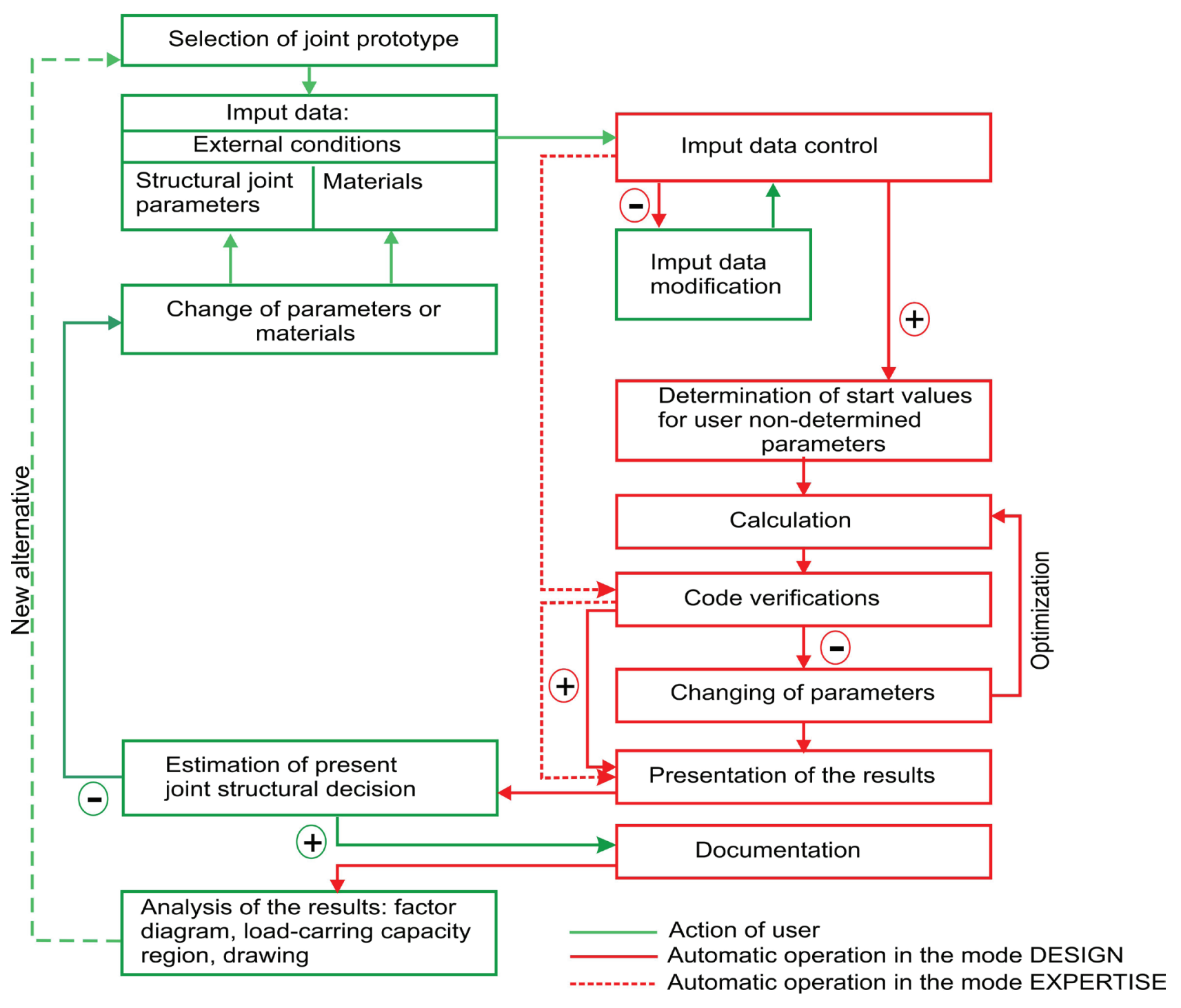

Figure 2. Generalized flow chart in the designer-software interaction mode. 
- implementation of all control verifications of whether the load-bearing capacity constraints as well as structural constraints are satisfied in the cases when all parameters of the joint are specified and can not be changed.

A generalized flowchart for solving the problem in the designer-software interaction mode corresponding to this concept is shown in Fig. 2. In fact, the role of the program can change from the "generator of all parameters" of the design specified by the user, taking into accounts the codes and external factors to the "simple check" of the capacity of the joint in accordance with the codes (the check of the parameters specified by the user). In cases when the values of some parameters have to be taken as fixed (user-defined), and all others are determined by the conditions of compliance with the codes, the program works according to the second variant. The program considers the parameters specified by the user as the same kind of initial data like the class of concrete or steel grade.

A role of the structural engineer is an important feature of the concept of searching/checking the parameters of the joint adopted in the program. $\mathrm{He}$ is responsible for the choice of the design, completeness and correctness of the loads taken into account and acting on the structure with the considered joint, as well as the analysis of the applicability of the obtained solution. If in the result of the analysis the designer changes some parameters, the program will perform the check and the search for such values of other parameters that would ensure the operation of the joint and would not contradict the codes.

\section{Input and control of the initial data}

Initial data include the information about the structural members connected in the considered joint, their sections and steel grades, joint's type (prototype), set of internal forces acting in adjacent sections of the connected structural members (see Fig. 3) as well as the data allowing to select the properties of the used bolted and welded connections (see Fig. 4).
Taking into account the fact that the joint has to work in different design situations, the program enables to specify the necessary number of internal forces combinations. These combinations can be specified by the user or be the result of the calculation performed by structural analyzer SCAD. The main requirement is the simultaneous action of forces included in one combination.

The check of the initial data is performed by the program both in the process of their specification

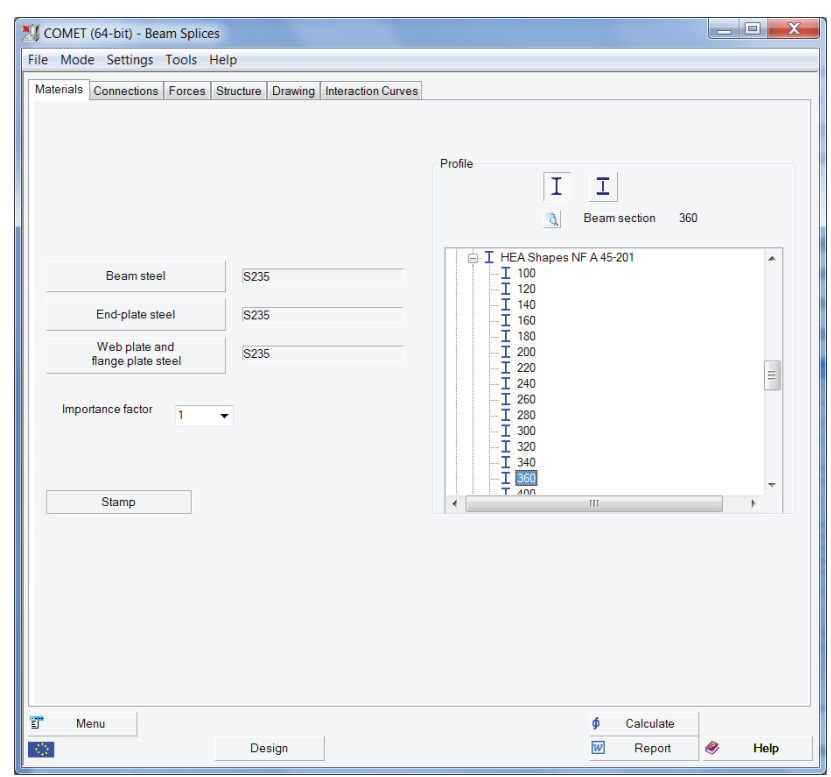

Figure 3. Dialog boxes for specifying the main initial data for beam splices.

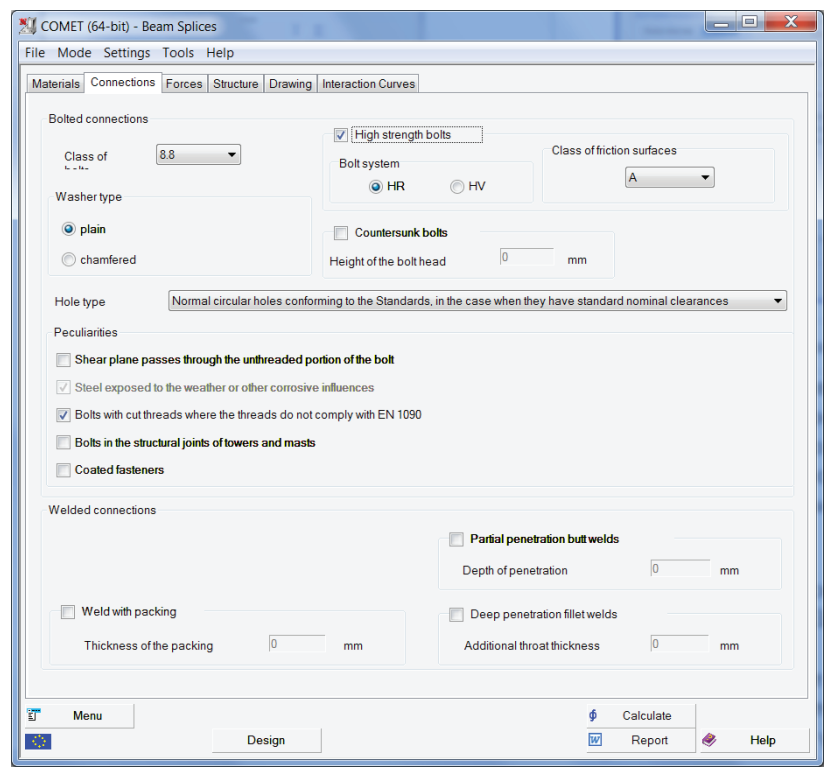

Figure 4. Dialog boxes to specify initial data for welded and bolted connections in structural joints 
(detection of formal errors) and in the design process. Diagnostic messages are generated on the basis of the check results.

\section{Software modes}

As noted above, the program enables to select the parameters of the joint on the basis of the design selected by the user and the conditions of its reliability and operability under the given operating conditions and materials (see Fig. 5).

If the joint is already operating in the real structure, i.e. all its parameters and operating conditions are known, the check of the joint can be performed, the results of which enable to make a justified decision about the possibility of the operation of the joint in the new conditions (for example, at high loads on the structure).

Thus, two fundamentally different modes have been implemented in the program - DESIGN and EXPERTISE, which are invoked by the respective buttons.

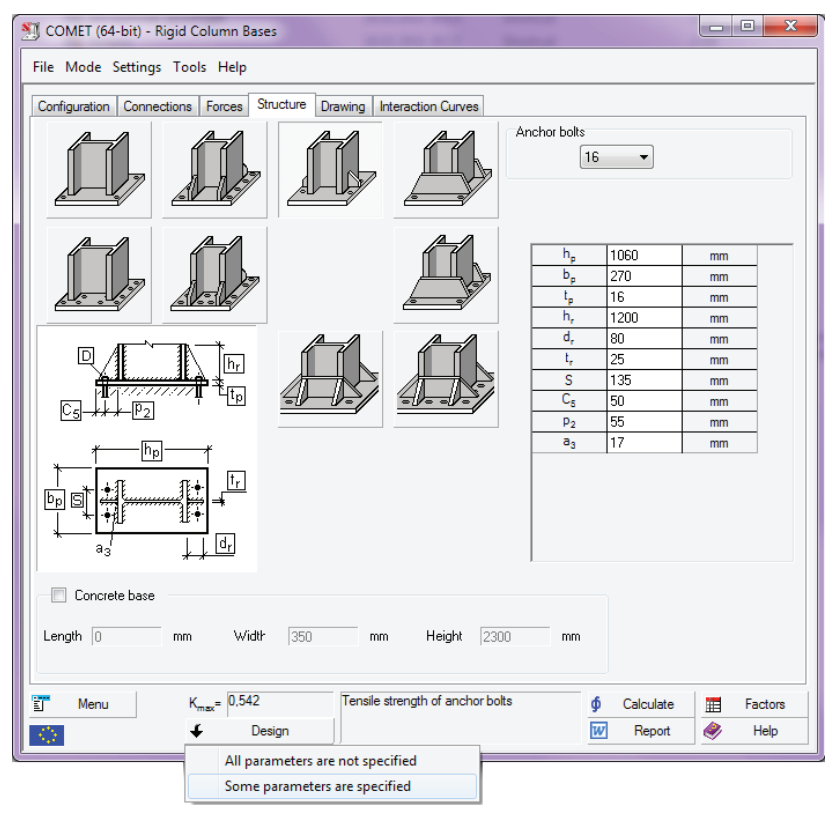

Figure 5. Control of the software mode: button «Design»-searching for structural joint's design decision (mode DESING: calculation of variable parameters and verification of the design decision), botton "Calculate»verification of the design decision (mode EXPERTISE)
If in the result of the design the parameters of the prototype provide the operability of the joint, but some of them can not be accepted because of the (possibly not formalized) requirements the designer knows, the list of the initial data can be extended by specifying the desired values for such parameters. At the same time, all other parameters not subject to the above requirements are set to zero and the design mode repeats.

When setting the parameters the program analyzes their values and reports detected violations of the design requirements. These can be strict guidelines on the need to change the specified values, or warnings about the violation of the recommendations of codes that can be ignored. Thus, the technology implemented in COMET supports the mode of active user decision making. Such a mode can both satisfy an experienced designer allowing him to achieve the necessary solution, and allow the beginner to solve a design problem with minimal interference in the decisionmaking process.

\section{Solution optimization}

If the design check indicates the need to change the design parameters, this change is performed in the program on the basis of the sensitivity analysis. The idea of this approach is considered below. Inequalities of the type $E_{d, i} \leq R_{d, i}$ should be satisfied in all checks between the design values of the action effects $E_{d, i}$ and the design strength $R_{d, i}$ according to the limit state calculation method adopted in EN 1990. It is more convenient to represent these inequalities in the following form:

$$
k_{i}=E_{d, i} / R_{d, i} \leq 1,0(i=1, \ldots, n)
$$

where $k_{i}$ is the utilization factor of the $i^{\text {th }}$ constraint, it is the reciprocal of the factor of safety. The value of the factors $k_{i}$ is a function of the governing design parameters $X_{j}(j=1, \ldots, p)$.

It should be noted that not all design parameters are independent. Some of them can be considered as governing, while others are unambiguously 
calculated at the known values of the governing parameters, and are not considered further. Moreover, some values of the parameters can be forced by the user; they are fixed and are not considered in the following description as well. Automatic selection of the unknown values of the internal parameters of a joint design is implemented as a multiple targeted improvement of a certain initial design of the joint in order to satisfy the bearing capacity constraints taking into account the structural and assortment constraints [6,7]. Multiple improvement of the design is performed on the basis of the analysis of its sensitivity to variation of the controlled parameters of the joint design. The response of the system, the values of the utilization factors of the load-bearing capacity constraints, is evaluated at each variation of a certain controlled parameter. Let's consider the case when it is necessary to improve the design that does not satisfy the requirements of the codes, since its check has shown that some of the inequalities (1) are violated and the utilization factor of the constraints is greater than one. If an increment $\Delta X_{s}$ is given to one of the parameters, for example $X_{s}$, all utilization factors can change obtaining new values $k_{i s}=k_{i}+\Delta k_{i s}$. It is logical to first use the change of the parameter $\Delta X_{r}$ for which the value of the greatest utilization factor of restrictions improves the most, i.e. $k_{j r}=\min _{s=1, \ldots, p} \max _{i=1, \ldots, n}\left(k_{i}+\Delta k_{i s}\right)$.

\section{PRESENTATION OF RESULTS}

Results of the design and verification are given as a diagram of checked factors, drawing with a preliminary design of the considered joint, a family of graphs bounding the region of the loadbearing capacity of the joint in the coordinate system of the selected internal forces and the report in RTF-format.

\section{Factors diagrams}

Results of the load-bearing capacity verifications for compliance with the requirements of design codes are given in the form of a factors diagram. Each factor is accompanied by a reference to the respective section of the code which regulates these requirements. The values of the factors are given in the form of the constraint utilization factors (see Fig. 6).

\section{Detail drawing}

A graphical representation of the designed joint is given in the form of a simplified drawing, which describes the structure completely and in detail, including the specification (see Fig. 7), but it does not take into account the manufacturer's technical requirements. In order to correct the drawing it

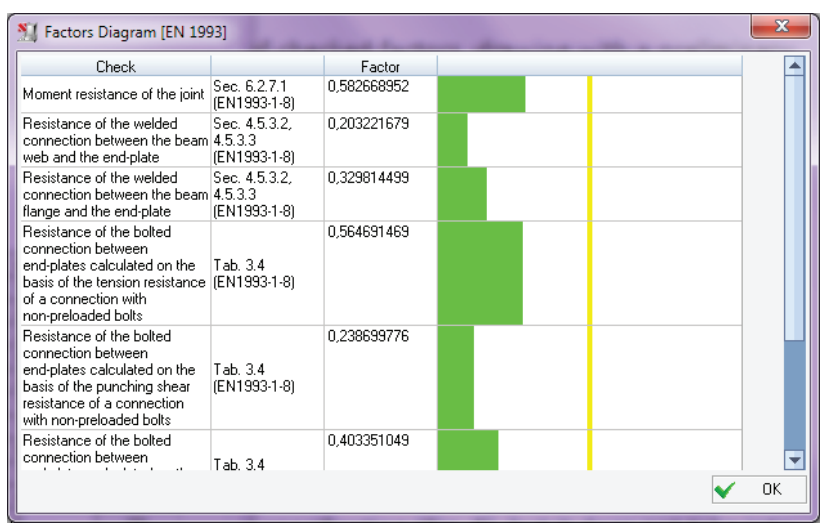

Figure 6. Factors diagram.

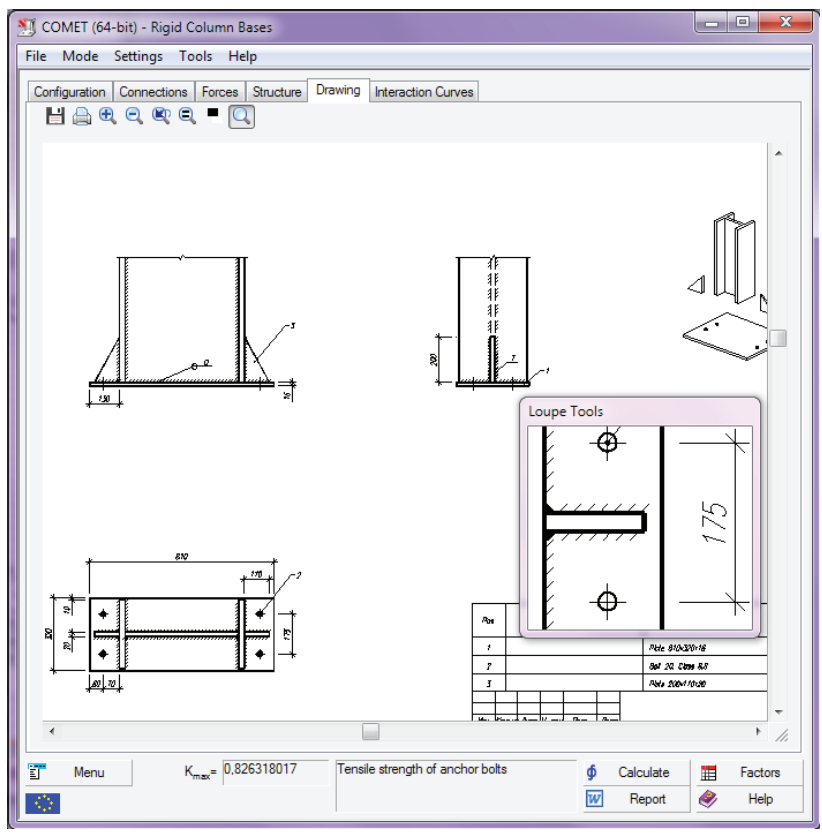

Figure 7. Design drawing on the screen. 
can be presented in DXF-format, a file that can be used by various graphic editors.

\section{Load-bearing capacity regions for structural joints}

Load-bearing capacity region for the structural joint is a family of graphs in the coordinate system of the selected internal forces bounding the region where all utilization factors are less or equal to one or, by other words, where all inequalities (1) are satisfied (see Fig. 8). Such family of graphs gives us a representation of the load-bearing capacity of the designed joint in terms of the selected design code [2].

Plotting each variant of such a region deals with a design verification of hundreds of internal forces combinations. It seems to us that such a large-scale verification has never been performed before.

The program also enables to show the position of points corresponding to the internal forces and to plot a convex shell on the basis of these points thus bounding the part of the load-bearing capacity region (see Fig. 8), which corresponds to any linear combination of design internal forces in the considered joint.

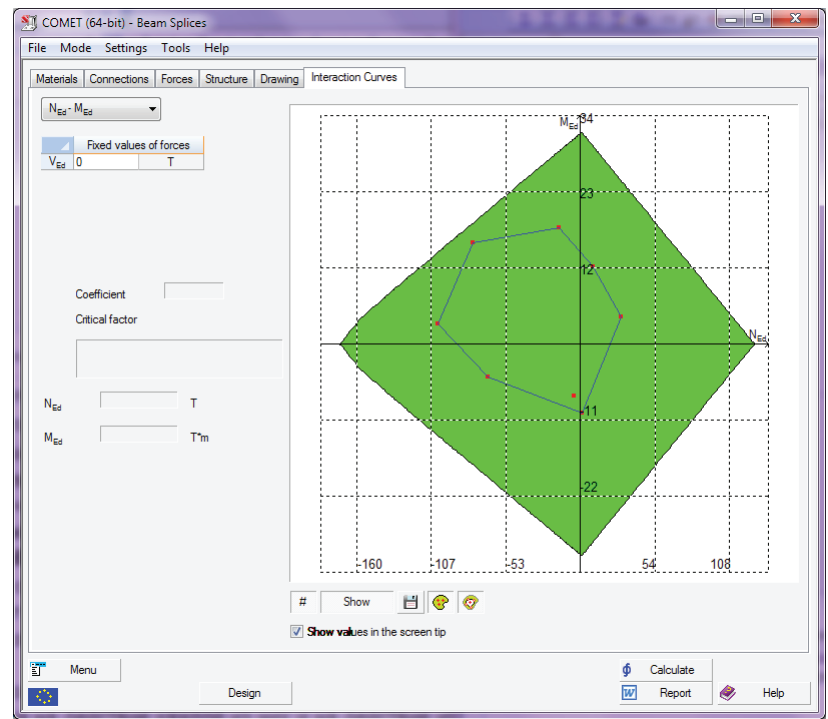

Figure 8. Plotting the load-bearing capacity region together with points corresponded to the acting internal forces in the joint and convex shell of internal forces.

\section{CONCLUSIONS}

Algorithm for designing each joint prototype has been presented as a set of operations implementing the rules for determining the interrelated values of the joint parameters. Searching of unknown joint parameters has been transformed to a decision making problem based on an analysis of mathematical model of the joint. Automatic searching of unknown joint parameters has been implemented as a multiple targeted improvement of a certain initial joint design in order to satisfy load-bearing capacity constraints taking into account the structural and assortment-based constraints. Multiple improvement of current joint design is performed on the basis of sensitivity analysis relative to variation of governing joint parameters.

\section{REFERENCES}

1. Dlubal Software GmbH. Add-on Module JOINTS. Design of Connections in Steel and Timber Structures. Program Description, 2015. Retrieved 18.01.2018 from http://www. dlubal.con/-/media/Files/website/documents/ manuals/rfem-and-rstab-add-on-modules/ connections/joints/joints-manual-en.pdf

2. Gavrilenko I.S., Girenko S.V., Perelmuter A.V., Perelmuter M.A., Yurchenko V.V. Load-bearing capacity as an interactive analysis tool in SCAD Office // Proceedings of the METNET Seminar 2017 in Cottbus / Eds. by Kuldeep Virdi \& Lauri Tenhunen. - Häme University of Applied Science, 2018. - P. 112-127.

3. Karpilovsky V., Kryksunov E., Mikitarenko M., Perelmuter A., Perelmuter M., Fedorovskyy V., Yurchenko V. SCAD Office. Realizacziya SNiP v proektiruyushhikh programmakh. [SCAD Office. Implementation of Design Codes in Computer-Aided Design Applications (in Russian)]. - Moscow, SCAD SOFT, 2010. $-432 \mathrm{p}$. 
4. Perelmuter A., Kryksunov E., Gavrilenko I., Yurchenko V. Designing bolted end-plate connections in compliance with Eurocode and Ukrainian codes: consistency and contradictions // Modern Building Materials, Structures and Techniques. Selected papers. - Vol. II. - Vilnius: VGTU, Vilnius Technika, 2010. - P. 733 - 743.

5. Sukhorukov V. Autodesk Robot Structural Analysis Professional. Proektnovy`chislitel`ny`j kompleks: Spravochnouchebnoe posobie. [Autodesk Robot Structural Analysis Professional. Design and Computation Complex: handbook and educational supplies (in Russian)] - Moscow, Association of Educational Civil Engineering Institutions of Construction, 2009. - $130 \mathrm{p}$.

6. Yurchenko V., Peleshko I. Improved gradient projection method for parametric optimisation of bar structures // Magazine of Civil Engineering, 2020. - No. 98(6). Article No. 9812. DOI: 10.18720/MCE.98.12.

7. Yurchenko V.V., Peleshko I.D. Searching for optimal pre-stressing of steel bar structures based on sensitivity analysis // Archives of Civil Engineering, 2020. - Vol. 66, No. 3. P. 525-540. DOI: 10.24425/ACE.2020.134411

\section{СПИСОК ЛИТЕРАТУРЫ}

1. Dlubal Software GmbH. Add-on Module JOINTS. Design of Connections in Steel and Timber Structures. Program Description, 2015. Retrieved 18.01.2018 from http://www. dlubal.con/-/media/Files/website/documents/ manuals/rfem-and-rstab-add-on-modules/ connections/joints/joints-manual-en.pdf
2. Gavrilenko I. S., Girenko S. V., PerelmuterA. V., Perelmuter M. A., Yurchenko V. V. Loadbearing capacity as an interactive analysis tool in SCAD Office // Proceedings of the METNET Seminar 2017 in Cottbus / Eds. by Kuldeep Virdi \& Lauri Tenhunen. - Häme University of Applied Science, 2018. P. $112-127$.

3. Карпиловский В.С., Криксунов Э.3., Микитаренко М.А., Перельмутер А.В., Перельмутер М.А., Федоровский В.Г., Юрченко B.B. SCAD Office. Реализация СНиП в проектирующих программах. - М.:, SCAD SOFT, 2010. - 432 p.

4. Perelmuter A., Kryksunov E., Gavrilenko I., Yurchenko V. Designing bolted end-plate connections in compliance with Eurocode and Ukrainian codes: consistency and contradictions // Modern Building Materials, Structures and Techniques. Selected papers. - Vol. II. - Vilnius: VGTU, Vilnius Technika, 2010. - P. 733 - 743.

5. Сухоруков В. Autodesk Robot Structural Analysis Professional. Проектно-вычислительный комплекс: Справочно-учебное пособие. - М.: Издательство Ассоциации Строительных вузов, 2009. - 128 с.

6. Yurchenko V., Peleshko I. Improved gradient projection method for parametric optimisation of bar structures // Magazine of Civil Engineering, 2020. - No. 98(6). Article No. 9812. DOI: 10.18720/MCE.98.12.

7. Yurchenko V.V., Peleshko I.D. Searching for optimal pre-stressing of steel bar structures based on sensitivity analysis // Archives of Civil Engineering, 2020. - Vol. 66, No. 3. P. 525-540. DOI: 10.24425/ACE.2020.134411 
Analysis and Design of Structural Steel Joints and Connection: Software Implementation

Viktor S. Karpilovsky, Candidate of Science; SCAD Soft, Ltd; Kyiv 03037, Ukraine, 3a Osvity street, office. 1,2; phones: +380442497193 (91), +380442487100, +38 04424880 60; e-mail: scad@scadgroup.com.

Eduard Z. Kriksunov, Candidate of Science; SCAD Soft, Ltd; Kyiv 03037, Ukraine, 3a Osvity street, office. 1,2; phones: +380442497193 (91), +3804424871 00, +38044248 80 60; e-mail: edk@scadsoft.com.

Anatolii $V$. Perelmuter, Foreign member of Russian Academy of Architecture and Construction Sciences, Doctor of Science, Professor; SCAD Soft, Ltd; Kyiv 03037, Ukraine, 3a Osvity street, office. 1,2; phones: +38 044249 7193 (91), +38 04424871 00, +38 04424880 60; e-mail: avp@scadsoft.com.

Vitalina V. Yurchenko, Doctor of Science, Professor; Kyiv National University of Construction and Architecture; Kyiv 03680, Ukraine, 32 Povitroflotskyj av.; phones: +38 0638926 491; e-mail: vitalina@scadsoft.com.
Карпиловский Виктор Семенович, кандидат технических наук; НПО СКАД Софт, 03037, Украина, г. Киев, ул. Просвящения, 3а, Офис 2; тел. +38 0442497193 (91), +38 044 $2487100,+380442488060$; E-mail: scad@scadgroup.com.

Криксунов Эдуард Зиновьевич, кандидат технических наук; НПО СКАД Софт, 03037, Украина, г. Киев, ул. Просвящения, 3а, Офис 2; тел. +38044249 7193 (91), +38 044 24871 00,+38 04424880 60; E-mail: edk@scadsoft.com.

Перельмутер Анатолий Викторович, иностранный член РААСН, доктор технических наук, профессор; НПО СКАД Софт, 03037, Украина, г. Киев, ул. Просвящения, 3а, Офис 2; тел. +38 0442497193 (91), +38 04424871 00,+38 04424880 60; E-mail: avp@scadsoft.com.

Юрченко Виталина Витальевна, доктор технических наук, профессор; Киевский национальный университет строительства и архитектуры, 03680, Украина, г. Киев, просп. Воздухофлотский, 32; тел. +38 0638926 491; E-mail: vitalina@scadsoft.com. 